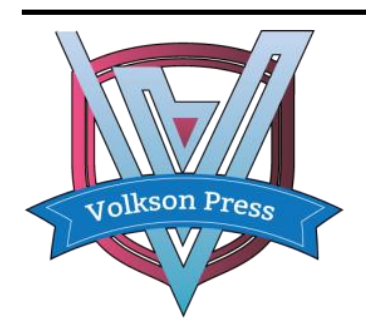

Contents List available at VOLKSON PRESS

Multidisciplinary Inclusive Education, Management

and Legal Services (MIEMLS)

Journal Homepage: https://topicsonsocialdevelop.com

DOI: 10.26480/ismiemls.01.2018.66.67

ISBN : 978-1-948012-13-3

\title{
THE IMPACT OF INTERNET FINANCE ON TRADITIONAL FINANCE
}

\author{
Xiang Xiaorui \\ Wuhan University of Technology, Wuhan, P.R. China, 430074 \\ Corresponding Author Email: 845504968@qq.com
}

This is an open access article distributed under the Creative Commons Attribution License, which permits unrestricted use, distribution, and reproduction in any medium, provided the original work is properly cited.

\section{ARTICLE DETAILS}

\section{Article History:}

Received 26 June 2018 Accepted 2 July 2018 Available online 1 August 2018

\section{ABSTRACT}

In recent years, Internet finance has achieved rapid development, which has brought certain challenges to the development of traditional finance. In particular, Internet finance, represented by Internet payment, P2P network lending, third-party payment and crowdfunding, has innovated in financial models, financial concepts, and financial operations methods, which has brought great challenges to traditional finance. The new competition has also spawned new cooperation. I believe that there will be more forms of Internet finance in the future. The challenge to traditional finance is enormous. We must look at the challenges and find common ground and new opportunities. Cooperation and win-win are the most important. At the same time, the regulatory authorities must do a good job in financial management in the Internet era to prevent financial risks in the Internet era.

\section{KEYWORDS}

Internet finance, traditional finance, challenge.

\section{INTRODUCTION}

Based on a study in China, the traditional financial model mainly includes banking, securities, insurance and other forms [1]. They are distinguished according to different business scopes and management forms, but the characteristics of complicated procedures and insufficient innovation are also the drawbacks of traditional financial development [2]. According to research, various forms of Internet financial products such as online financial management, network insurance, and network microfinance have emerged, which indicates the emergence and rapid development and growth of Internet finance [3]. Internet finance has a subtle influence on consumers with its convenient and efficient quality features. Study showed consumer behavior has also had a huge impact on the traditional financial industry [4]. The following is a specific study on the challenges of Internet finance to traditional finance.

\section{BASIC ANALYSIS OF TRADITIONAL FINANCE AND INTERNET FINANCE}

Finance is the collective name for the economic business of Fu'an in currency circulation and communication activities. Traditional finance usually refers to financial activities with three basic business contents: deposit, loan and payment settlement. From a macro perspective, traditional finance refers to a variety of capital operations such as currency exchange settlement, currency issuance and preservation, and precious metal trading. Microscopically, traditional finance refers to the integration of credit money. Internet finance refers to a mixed form of financial system. Under the Internet system, the financial industry gradually penetrated the Internet, and many online tools and platforms gradually covered the related businesses of traditional finance, which led to the emergence of Internet finance [5]. From a macro perspective, ecommerce, third-party payment and credit rating assessment are all part of Internet finance. Microscopically, the form of transactions in which the circulation of funds depends on the network platform is Internet finance.

Based on a study, the development of Internet finance is inevitable, and it is also the progress of the development of the times [6]. It is different from traditional finance. According to a scholar, the emergence of Internet finance has provided a corresponding direction for change in traditional finance, bringing new vitality to traditional finance [7]. Along with this, it has brought huge innovations, but it is worth noting that they cannot be opposed to each other. We must seize the new opportunities and continue to develop. For traditional banks, with a stable customer base, Internet finance can be vigorously developed. Through the processing and analysis of data, we will continue to enrich network financial products.

\section{THE DEVELOPMENT OF INTERNET FINANCE HAS CHANGED CHINA'S FINANCIAL ENVIRONMENT.}

In 2013, China's Internet finance attracted a lot of attention. In 2014, Internet finance entered the government work report for the first time. Internet of Things finance came into being under the situation of rapid development of computer network technology in China. It is an inevitable outcome of the sustainable development of the financial sector and the continuous improvement of the level of science and technology. In the emerging field, the positive effects it brings are enormous. Compared with other developed regions in the world, its scale of development is unprecedented. The term Internet finance seems to exist only in China, and there is no established Internet finance for the whole world. Internet finance in the world only stays at the level of payment, and does not breed a new financial format. In China, the main forms of Internet finance include online payment, credit, crowdfunding, etc. However, compared with these businesses, the scale of related business development in other countries is very small, and it has not developed into the effect of national concern as in China.

Internet finance is "out of the box" in China, mainly due to the macro background of financial repression in China's financial system and the regulatory arbitrage of financial services involved in Internet finance. China's financial system has long been in the "financial repression" described by economists McKinnon and Shaw. Interest rates are regulated and funds are mainly allocated by the banking system. And the profitseeking market will certainly try to take advantage of any arbitrage space that may arise from regulation. The backwardness and supply of traditional financial services are insufficient, and the huge financing needs of the real economy have not been met, leaving room for the development of Internet finance. The high regulation of traditional financial markets has a blind spot for financial innovation, making Internet finance a new market entry. There is a chance to survive. This is the basic logic for Internet finance to flourish in China. The fundamental support is institutional factors. Financial operations through the Internet are a huge challenge or 
even a subversion of traditional finance.

\section{THE IMPACT OF INTERNET FINANCE ON TRADITIONAL FINANCE}

\subsection{Enrichment of financial transactions}

With the popularity of Internet technology, more and more people are proficient in the payment technology of mobile phones, tablet computers and other clients, and completing transactions through modern payment methods has become a common problem for most people. By completing the payment behavior through a mobile phone or a PC terminal, it is possible to save a lot of payment behavior that can only be done by the bank in the past, and save a lot of trouble. Many people can complete many trading activities without leaving their homes, which is convenient and fast and saves a lot of time. This is an important aspect of the Internet to change people's living habits. According to incomplete statistics, the number of Internet users in China is rising. Today, through Internet consumption, the payment of various living expenses has become the transaction content that most people complete online, such as utilities and communication fees.

\subsection{Constantly impacting the banking system}

The banking system we are currently exposed to is usually developed under the premise of traditional finance. The related businesses involved in traditional banks have stricter orders and standards, and bank managers are better at ensuring security during the transaction. And reliability, generally have a clear and strict definition of the entire financial transaction process, the bank's credit situation and the capital flow business, causing the bank to get into trouble in the course of actual operations. Since entering the new Internet era, along with the advancement of domestic Internet technology and the rapid expansion of the financial sector, any domestic bank has launched related business activities, not only to be able to adapt to Internet finance faster and better. The change is also to be able to quickly improve the economic and social benefits of the bank.

\subsection{Changed the funding model of enterprises}

In the traditional financial industry, the supply of corporate funds needs to adopt the development model of traditional capital supply and depends on the scale effect generated by the supply of funds. However, the development of Internet finance has led some companies to start to use funds as a center for demand and to start using different lending methods. In this context, enterprises do not need to be restricted by traditional financial intermediaries to handle related wealth management services, but can directly use the WeChat, QQ, Weibo and other platforms on the Internet to manage their wealth management business, so they can give money management to enterprises. Great convenience has come. At the same time, some traditional financial structures have also improved the past credit evaluation system to adapt to the changing supply and demand model of corporate funds. In addition, along with the expansion of investment channels, many insurance companies and securities companies have begun to cooperate with e-commerce websites to launch financial products, so that users can use the Internet to complete financial transactions without going out, and then make traditional enterprises get rid of the past. The funding supplies development model.

\section{CONCLUSION}

All in all, under the impact of the development of Internet finance, the boundaries of the traditional financial industry have been broken. In general, under the impact of the development of Internet finance, the boundaries of the traditional financial industry have been broken, and in the face of this development, traditional financial institutions have to Carry out the improvement of its own operation level. Internet finance is an important trend in the future development. The traditional financial service industry should recognize its own development direction and follow the trend of development. After understanding the development characteristics of the Internet finance industry, we will respond positively, make efforts to make changes, and develop better in the financial industry.

\section{REFERENCES}

[1] Bao, A.M. 2013. Challenges and Risk Prevention of Internet Finance to Traditional Finance. Inner Mongolia Financial Research, (12), 24-26.

[2] Li, Y.J. 2014. On the Challenge of Internet Finance to Traditional Commercial Banks. Finance and Economics, (3), 14-16.

[3] Cao, F.Q. 2015. The Challenge of Internet Finance to Traditional Finance. Financial Forum, 1, 3-6, 65

[4] Teng, B. 2016. The Challenge of Internet Finance to Traditional Finance. Modern Marketing, 2, 10-11.

[5] Yin, Y. 2016. Discussion on the Challenge of Internet Finance to Traditional Finance. Modern Marketing, (8), 100-101.

[6] Huang, W. 2014. The Challenge of Internet Finance to Traditional Finance. Brand, (8): 61.

[7] Yang, C. 2015. On the Challenge of Internet Finance to Traditional Finance. Shopping Mall Modernization, (1), 130-131. 